\title{
Efficacy and safety of human papilloma virus vaccine in cervical cancer prevention: systematic review and meta-analysis
}

\author{
Lucila Rey-Ares, $M D^{a}$, Agustín Ciapponi, $M D^{a, b}$ and Prof. Andrés Pichon-Riviere, $M D^{a, c}$
}

\begin{abstract}
SUMMARY
Introduction. Cervical cancer is the third most common cancer worldwide. The human papilloma virus (HPV) has been identified as the etiologic agent of cervical and other anogenital cancers. The aim was to perform a systematic review and meta-analysis to evaluate the efficacy and safety of HPV vaccines in preventing cervical intraepithelial neoplasias (CIN) grades 2 and 3, adenocarcinoma in situ (CIN2+) and cervical cancer.

Materials and Methods. Major bibliographic databases were searched in July 2011 without any temporal nor language restrictions. Randomizedcontrolled trials that evaluated the efficacy of $\mathrm{HPV}$ vaccines against CIN2+ and cervical cancer were included.

Results. Four of the 168 publications found were included in a meta-analysis. Among vaccinated women, the relative risk (RR) of developing CIN2+ lesions was 0.45 (95\% CI 0.38 to 0.54$)$ for HPV 16, 0.14 (0.08 to 0.25 ) for HPV 18, and 0.79 (0.68 to 0.93 ) for oncogenic serotypes not included in the vaccines $31 / 33 / 45 / 52 / 58$. All studies had acceptable safety profiles.

Conclusions. Vaccines currently available are effective, safe and capable of preventing CIN2+ lesions, although long term efficacy has not yet been fully tested.

Key words: vaccines, papillomavirus vaccines, uterine cervical neoplasm, female, systematic review and meta-analysis.
\end{abstract}

a. Instituto de Efectividad Clínica y Sanitaria (IECS). Buenos Aires.

b. Family and Community Medicine Division, Hospital Italiano de Buenos Aires.

c. Public Health School, School of Medicine, University of Buenos Aires. Buenos Aires, Argentina.

E-mail Address: Lucila Rey-Ares, MD: lreyares@iecs.org.ar

Conflict of Interest: None.

Received: 3-20-2012 Accepted: 6-4-2012 http://dx.doi.org/10.5546/aap.2012.483

\section{INTRODUCTION}

Cervical cancer is the third most common cancer among women worldwide and constitutes a major public health problem. According to GLOBOCAN, the International Agency for Research on Cancer Registry, ${ }^{1} 68,220$ out of the 530,000 cases diagnosed globally in 2008 occurred in Latin America and the Caribbean. Developing countries carry over $85 \%$ of the global burden of the disease; in these countries cervical cancer accounts for $13 \%$ of all female cancers. Latin America and the Caribbean are a high risk region, with an incidence (age standardized rate) of 23.5/100,000 inhabitants and a mor- tality rate of 10.8/100,000 inhabitants.

The link between the human papilloma virus (HPV) and cervical cancer was first suggested in the 1970s. ${ }^{2}$ Then, several epidemiological and molecular studies provided undeniable evidence about the role of HPV as an etiologic agent of cervical cancer and other anogenital cancers that share epidemiological characteristics with sexually transmitted diseases., ${ }^{3,4}$ Less often, HPV has been associated with oropharyngeal cancers and respiratory papillomatosis.

More than $35 \mathrm{HPV}$ types infect the genital tract: the most common being $6,11,16$ and 18 . The first two types are considered low risk, because they are seldom found associated with an invasive cervical cancer, unlike serotypes 16 and 18, considered high risk. ${ }^{3,4}$

Persistent HPV infection may result in pre-neoplastic lesions, cervical intraepithelial neoplasias (CINs) classified into 3 grades according to histopathological criteria, adenocarcinoma in situ (AIS), or invasive cervical cancer. CIN 1 indicates the presence of an active HPV infection, CIN 2 and 3 are considered pre-malignant lesions and, therefore, as in AIS and cervical cancer, treatment should be indicated.

A recently published meta-analysis $^{5}$ shows that in Latin America and the Caribbean $82.5 \%$ of CIN 2 and 3 lesions and $89 \%$ of cervical cancers were positive for $\mathrm{HPV}$, with a percentage attributable to HPV 16/18 similar to figures reported worldwide.

Among measures implemented for the prevention of cervical cancer, the detection of pre-malignant cervical lesions via PAP smear tests and colposcopy have proven to be highly successful to reduce cervical cancer incidence and mortality all over the world. 
Non-infectious, adjuvanted vaccines have been developed to reduce the burden of HPV infection and related diseases. The vaccines contain virus-like particles (VLPs) for HPV types 16, 18, 6, and 11 (tetravalent) and for HPV types 18 and 16 (bivalent).

These vaccines have generated a lot of excitement in the medical community and the public at large. Lately, they have been included in official immunization schedules of several countries, ${ }^{6}$ including Argentina.

Given the rare occurrence of cervical cancer, studies evaluating the vaccine efficacy have used the following surrogate endpoints for this disease: persistent HPV infection, CIN 1, 2, 3 lesions, and AIS. The latter is one of the most controversial issues $^{7,8}$ when interpreting efficacy outcomes. Both the World Health Organization and the FDA (Food and Drug Administration) $)^{9-11}$ consider CIN 2+ (CIN 2, CIN 3, and AIS) lesions valid surrogate endpoints to assess the effectiveness of HPV vaccines.

$\mathrm{HPV}$ vaccination is a major public health intervention that involves a large percentage of the population. Its implementation has an impact on countries' budgets and gives rise to significant healthcare consequences in the long term. Therefore, sound information is critical to make decisions, especially in middle- and low-income countries as those in Latin America and the Caribbean region.

The aim of this study was to evaluate the available evidence about HPV vaccine efficacy and safety for the prevention of cervical cancer through a systematic review and meta-analysis.

\section{MATERIAL AND METHODS}

A search was made in bibliographic databases, such as MEDLINE, the Cochrane Central Register of Controlled Trials (CCTR), DARE and NHS EED. A second search was carried out in MEDLINE, LILACS, EMBASE and DARE, mainly focused on finding economic assessments of the $\mathrm{HPV}$ vaccine conducted in Latin America and the Caribbean. The search was complemented in generic web based browsers and agencies of health technology assessment with the use of the following keywords: papillomavirus vaccines, HPV vaccine, Cervarix ${ }^{\circledast}$ and Gardasil ${ }^{\circledR}$.

Studies that met the inclusion criteria were randomized, controlled trials evaluating the efficacy of bivalent and tetravalent vaccines. Only endpoints corresponding to CIN2+ lesions or cervical cancer have been considered in this systematic review and meta-analysis, as per inten- tion-to-treat analysis.

Two of the authors (AC, LRA) independently selected the studies and evaluated their methodological quality. Discrepancies were solved by consensus of the whole team (AC, APR, LRA). The software used was Review Manager 5.1 (RevMan). The random effect method was used to account for the possible clinical or methodological heterogeneity and, at the same time, provide more conservative estimates (wider confidence intervals).

\section{RESULTS}

A total of 168 articles were identified, out of which 91 studies were selected for a full-text assessment. Finally, four publications of three randomized controlled trials ${ }^{12-15}$ were included to develop the vaccine efficacy meta-analysis, and ten economic assessments (Figure 1) were used to evaluate vaccination cost-effectiveness in the region.

Studies included were phase III, multicenter, randomized, controlled clinical trials. Two of them were conducted in America, Asia and Europe, whereas the third one was conducted only in the American continent (USA, Canada, and Brazil). The three studies, of a high methodological quality, included a total of 190,534 women of ages ranging between 15 and 25 years old, with no history of HPV genital lesions nor infection. Those assigned to the vaccine arm were administered 3 doses of bivalent or tetravalent vaccine, whereas those in the control arm received either placebo or hepatitis A vaccine. The mean follow-up in all the studies together was 42.8 months, and they were carried out between 2003 and 2005 (Table 1).

HPV-16 related CIN2+: The combined relative risk (RR) from the meta-analysis of the 3 randomized, controlled clinical trials, which included 31,955 patients, was 0.45 (95\% CI 0.38-0.54) in the intention-to-treat analysis, which corresponds to a relative risk reduction (RRR) of $55 \%$ for vaccinated women. Even though the heterogeneity for this meta-analysis is quite important ( $\left.\mathrm{I}^{2} 91 \%\right), 80 \%$ of relevance is given by the large RR study (FUTURE I and II). Therefore, the central estimate by the meta-analysis is the most conservative one, less influenced by the rest of the studies (Figure 2).

HPV-18 related CIN2+: The intention-to-treat analysis on a total of 33,046 women showed a significant benefit for the vaccinated group, with a pooled RR of 0.14 (95\% CI 0.08-0.25), which corresponds to a RRR of suffering CIN2+ lesions of $86 \%$ in vaccinated women. In this case heterogeneity was null ( $\left.\mathrm{I}^{2} 0 \%\right)$ (Figure 3). 
HPV-31/33/45/52/58 related CIN2+: With respect to lesions caused by oncogenic HPV types not included in the vaccine, the meta-analysis showed a statistically significant RRR $(p=0.004)$ of $21 \%$ (RR $0.79 ; 95 \%$ CI $0.68-0.93$ ) in the group of vaccinated women out of a total of 34,383 women enrolled. A significant heterogeneity was observed with a $\mathrm{I}^{2}$ of $71 \%$. It is then estimated that there is approximately $20 \%$ of cross-protection against oncogenic serotypes not included in the vaccine (Figure 4).

With respect to vaccine safety, all studies have shown acceptable safety profiles. In the study PATRICIA $^{12}$ no differences were found between the vaccinated group and the control group in any of the considered endpoints. In the two remaining studies ${ }^{14,16,17}$ a larger number of non-serious adverse events were observed in the vaccinated group, the most frequent being local adverse events (redness, itching, tenderness and swelling in the injection site). No differences among groups regarding serious adverse events and pregnancy-related adverse events (miscarriage, congenital malformations, preterm birth, etc.) were found in any of the studies.

\section{DISCUSSION}

Primary prevention programs targeted at sexually transmitted disease prevention and screening via Pap smear tests continue to be an effective measure for cervical cancer prevention, early detection, and treatment.

The fact of having an effective and safe vaccine that is able to prevent HPV serotypes 16 and 18 related CIN2+ lesions is promising, even though there is not enough evidence to support the replacement of routine screening techniques by the vaccine.

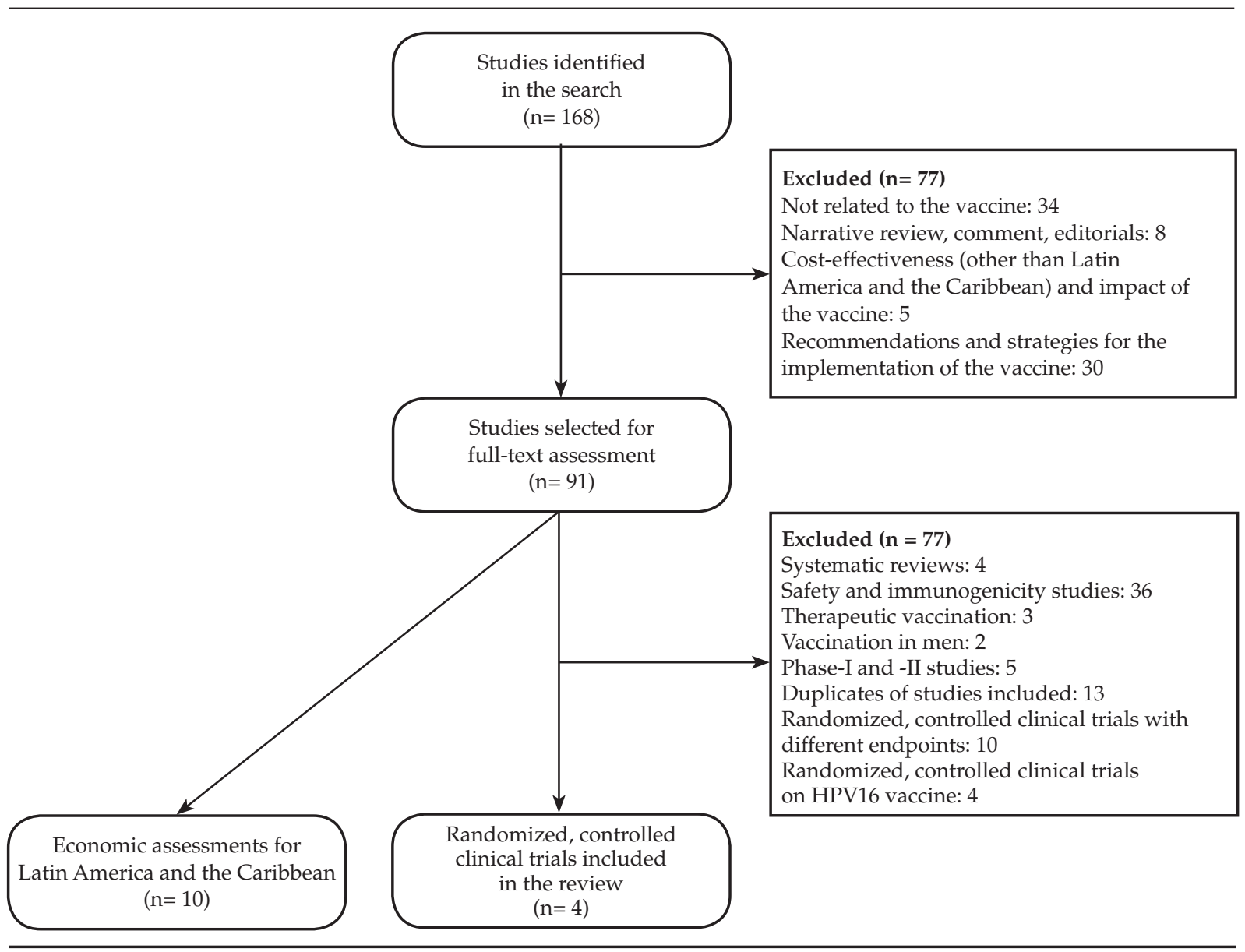


TABLE 1. Characteristics of the studies included in the meta-analysis

\begin{tabular}{|c|c|c|c|}
\hline & Harper 2006 & FUTURE I \& II & PATRICIA \\
\hline Publications used & Harper 2006 & Wheeler 2009 and Muñoz 2010 & Paavonen 2009 \\
\hline Phase & III & III & III \\
\hline Number of sites & 28 & $62 / 90$ & 135 \\
\hline Number of countries & 3 & $16 / 13$ & 14 \\
\hline Enrollment date & $11 / 2003-7 / 2004$ & $1 / 2002-5 / 2003$ & $5 / 2004-6 / 2005$ \\
\hline Funding & GlaxoSmithKline & Merck & GlaxoSmithKline \\
\hline \multicolumn{4}{|l|}{ Inclusion criteria } \\
\hline Age (years) & $16-25$ & $15-26$ & $15-25$ \\
\hline No. of sexual partners & $\leq 5$ & $\leq 4$ & $\leq 6$ \\
\hline Exclusion criteria & $\begin{array}{l}\text { Pregnancy or history of } \\
\text { abnormal Pap smears }\end{array}$ & $\begin{array}{l}\text { Previous HPV infections, } \\
\text { history of abnormal Pap } \\
\text { smears or genital warts }\end{array}$ & $\begin{array}{l}\text { History of colposcopy } \\
\text { pregnancy, breastfeeding, } \\
\text { chronic or autoimmune } \\
\text { diseases }\end{array}$ \\
\hline \multicolumn{4}{|c|}{ Intervention and comparator } \\
\hline Vaccine components & HPV 16, 18 VLPs & HPV 6, 11, 16, 18 VLPs & HPV 16, 18 VLPs \\
\hline Comparator & Placebo & Placebo & Hepatitis A vaccine \\
\hline Vaccination schedule & 0,1 and 6 months & 0,2 and 6 months & 0,1 and 6 months \\
\hline \multicolumn{4}{|l|}{ Follow-up protocol } \\
\hline Viral DNA search & every 6 months & every 6 months & every 6 months \\
\hline PAP smear & every 6 months & every $6 / 12$ months & every 12 months \\
\hline Follow-up (months) & $\begin{array}{l}\text { Baseline study } 27 \text { and follow- } \\
\text { up study } 53\end{array}$ & 36 (mean) & 39.4 (mean) \\
\hline \multicolumn{4}{|l|}{ Endpoints } \\
\hline Primary & $\begin{array}{l}\text { Incidence of infection for HPV } \\
16 \text { and/or } 18\end{array}$ & $\begin{array}{l}\text { Incidence of genital warts } \\
\text { CIN 1-3, VIN 1-3; AIS, vulvar } \\
\text { cancer HPV 6, 11, } 16 \text { or } 18 \\
\text { related vaginal or cervical } \\
\text { cancer }\end{array}$ & $\begin{array}{c}\text { CIN2+ lesions HPV } 16 \text { and/or } \\
18 \text { related }\end{array}$ \\
\hline Secondary & $\begin{array}{c}\text { Persistent infection for } \\
\text { HPV } 16 \text { and/or } 18 \\
\text { LSIL, HSIL, CIN 1-3 and } \\
\text { cervical cancer related to HPV } \\
16 \text { and/or } 18\end{array}$ & $\begin{array}{c}\text { Persistent infection, CIN 1-3 } \\
\text { and AIS related to HPV 31, 33, } \\
45,52,58 \\
\text { Combined incidence of CIN } \\
\text { 1-3, AIS and cancer for HPV 6, } \\
\text { 11, } 16 \text { and/or } 18\end{array}$ & $\begin{array}{l}\text { Persistent infection for } \\
\text { HPC } 16 \text { and/or } 18 \text { or other } \\
\text { oncogenic types, CIN lesions } \\
\text { associated to HPV 16, } 18, \\
\text { other oncogenic types or } \\
\text { without isolation of viral } \\
\text { DNA. Decrease in colposcopy } \\
\text { and excisional procedures }\end{array}$ \\
\hline \multicolumn{4}{|c|}{$\begin{array}{l}\text { Population for the analysis } \\
\text { of efficacy }\end{array}$} \\
\hline Per protocol analysis & $\begin{array}{l}\text { All those participants that } \\
\text { received } 3 \text { doses of vaccine } \\
\text { or placebo, with a negative } \\
\text { HPV DNA test on day } 1 \text { and } \\
\text { seronegative for HPV } 16 \text { and/ } \\
\text { or } 18 \text {. No protocol deviations }\end{array}$ & $\begin{array}{l}\text { All those participants that } \\
\text { received } 3 \text { doses of vaccine } \\
\text { or placebo in one year, } \\
\text { seronegative, with a negative } \\
\text { DNA testing for HPV 6, 11, } 16 \\
\text { or } 18 \text { on day } 1 \text { and that kept } \\
\text { the DNA testing negative in } \\
\text { the first } 7 \text { months of follow-up. } \\
\text { No protocol deviations }\end{array}$ & $\begin{array}{l}\text { All those participants that } \\
\text { received } 3 \text { doses of vaccine or } \\
\text { placebo with a negative HPV } \\
\text { DNA test, seronegative for } \\
\text { HPV } 16 \text { and/or } 18 \text { and with } \\
\text { normal or low-grade cytology } \\
\text { on day } 1 \text {. No protocol } \\
\text { deviations }\end{array}$ \\
\hline Intention-to-treat & $\begin{array}{l}\text { All those participants that } \\
\text { received at least } 1 \text { dose of } \\
\text { vaccine or placebo, with } \\
\text { negative HPV DNA testing. } \\
\text { With available data to assess } \\
\text { efficacy } \\
\end{array}$ & $\begin{array}{l}\text { All those participants } \\
\text { randomized without } \\
\text { considering the history of } \\
\text { anogenital lesions or HPV } \\
\text { infection }\end{array}$ & $\begin{array}{l}\text { All women that received at } \\
\text { least } 1 \text { dose of the vaccine or } \\
\text { placebo with normal or low- } \\
\text { grade cytology on day } 1 \text { and } \\
\text { with available data to assess } \\
\text { efficacy }\end{array}$ \\
\hline \multicolumn{4}{|l|}{ Methodological quality } \\
\hline Randomization & Adequate & Adequate & Adequate \\
\hline Masking & Adequate & Adequate & Adequate \\
\hline Lost-to-follow-up report & Yes & Yes & Yes \\
\hline Expected efficacy (1-RR) & 0.7 & $0.80-0.90$ & 0.85 \\
\hline Sample size calculation & Yes & Yes & Yes \\
\hline
\end{tabular}

Pap smear test: Papanicolaou test; LSIL: low squamous intraepithelial lesion; HSIL: high squamous intraepithelial lesion; CIN: cervical intraepithelial neoplasia; CC: cervical cancer; AIS: adenocarcinoma in situ, VIN: vulvar intraepithelial neoplasia. 
The long-term efficacy of the vaccine to prevent cervical cancer has not yet been proven. Therefore, only long-term follow-up of cohorts of vaccinated patients will show vaccine actual efficacy in prevention in the future.

Pre-adolescence vaccination, together with the Pap smear screening and the prevention of sexually transmitted diseases are considered as the most comprehensive and valid strategy to prevent cervical cancer. This strategy has already been adopted by many countries.
The possible inclusion of the vaccine as a primary prevention measure has elicited a great interest in the world, and especially in the region. Several economic assessments ${ }^{18-27}$ have been conducted, aiming at analyzing the cost-effectiveness of this intervention in different middle- or low-income countries, such as Argentina, Brazil, Chile, Colombia, Mexico, and Peru. Although the methodologies and scenarios used varied, in all studies, cost-effectiveness results were highly dependent on the cost of the vaccine.

FIGURE 2. HPV-16 related CIN2+

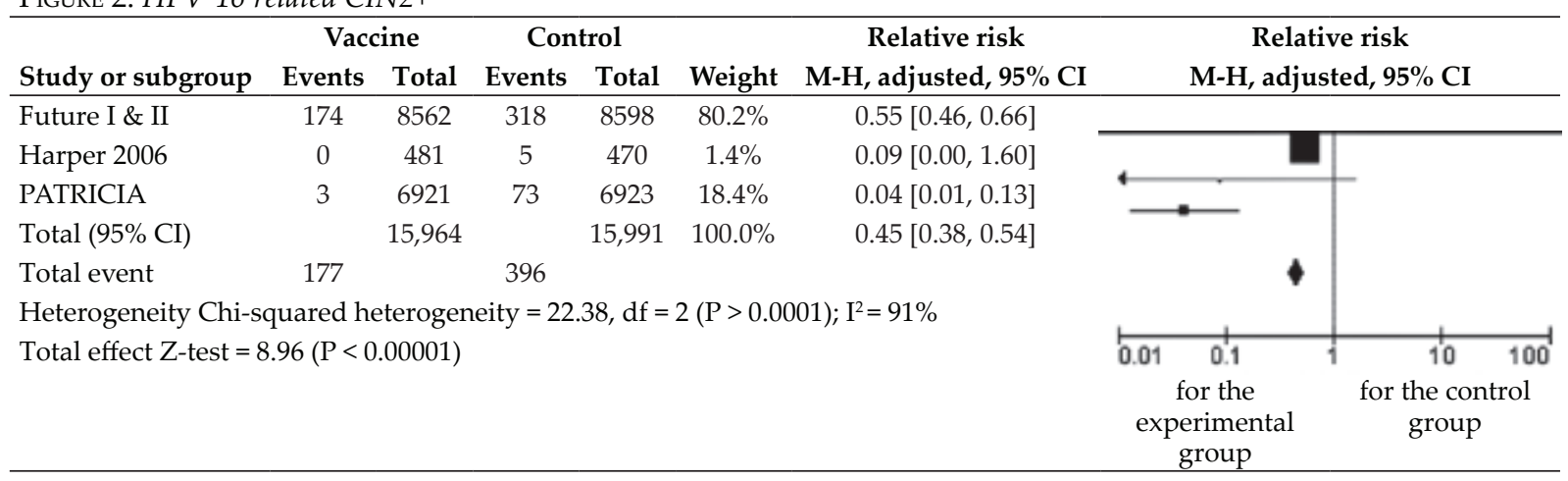

FIgURE 3. HPV-18 associated CIN2+

\begin{tabular}{|c|c|c|c|c|c|c|c|c|}
\hline \multirow[b]{2}{*}{ Study or subgroup } & \multicolumn{2}{|c|}{ Vaccine } & \multicolumn{2}{|c|}{ Control } & \multirow[b]{2}{*}{ Weight } & \multirow{2}{*}{$\begin{array}{c}\text { Relative risk } \\
\text { M-H, adjusted, } 95 \% \text { CI }\end{array}$} & \multirow{2}{*}{\multicolumn{2}{|c|}{$\begin{array}{c}\text { Relative risk } \\
\text { M-H, adjusted, } 95 \% \text { CI }\end{array}$}} \\
\hline & Events & Total & Events & Total & & & & \\
\hline Future I \& II & 11 & 8562 & 71 & 8598 & $74.7 \%$ & $0.16[0.08,0.29]$ & & \\
\hline Harper 2006 & 0 & 481 & 0 & 470 & & Not calculated & & \\
\hline PATRICIA & 2 & 7455 & 24 & 7480 & $25.3 \%$ & $0.08[0.02,0.35]$ & & \\
\hline Total $(95 \% \mathrm{CI})$ & & 16,498 & & 16,548 & $100.0 \%$ & $0.14[0.08,0.25]$ & & \\
\hline Total event & 13 & & 95 & & & & & \\
\hline \multicolumn{9}{|c|}{ Heterogeneity Chi-squared heterogeneity $=0.60 \mathrm{df}=1(\mathrm{P}=0.44) ; \mathrm{I}^{2}=0 \%$} \\
\hline \multicolumn{7}{|c|}{ Total effect Z-test $=6.72(\mathrm{P}<0.00001)$} & $0.01 \quad 0.1$ & 10100 \\
\hline & & & & & & & $\begin{array}{l}\text { for the } \\
\text { experimental } \\
\text { group }\end{array}$ & $\begin{array}{l}\text { for the control } \\
\text { group }\end{array}$ \\
\hline
\end{tabular}

Figure 4. HPV-31/33/45/52/58 associated CIN2+

\begin{tabular}{|c|c|c|c|c|c|c|c|c|c|c|}
\hline \multirow[b]{2}{*}{ Study or subgroup } & \multicolumn{2}{|c|}{ Vaccine } & \multicolumn{2}{|c|}{ Control } & \multirow[b]{2}{*}{ Weight } & Relative risk & \multirow{2}{*}{\multicolumn{4}{|c|}{$\begin{array}{c}\text { Relative risk } \\
\text { M-H, adjusted, } 95 \% \text { CI }\end{array}$}} \\
\hline & Events & Total & Events & Total & & M-H, adjusted, $95 \%$ CI & & & & \\
\hline Future I \& II & 216 & 8562 & 253 & 8598 & $75.3 \%$ & $0.86[0.72,1.03]$ & & & & \\
\hline PATRICIA & 49 & 8602 & 83 & 8621 & $24.7 \%$ & $0.59[0.42,0.84]$ & & $\rightarrow$ & & \\
\hline Total $(95 \% \mathrm{CI})$ & & 17,164 & & 17,219 & $100.0 \%$ & $0.79[0.68,0.93]$ & & & & \\
\hline Total event & 265 & & 336 & & & & & 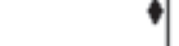 & & \\
\hline \multicolumn{11}{|c|}{ Heterogenicidad Chi-squared heterogeneity $=3.39, \mathrm{df}=2(\mathrm{P}=0.07) ; \mathrm{I}^{2}=71 \%$} \\
\hline \multicolumn{7}{|c|}{ Total effect Z-test $=2.88(\mathrm{P}=0.004)$} & 0.01 & 0.1 & 10 & 100 \\
\hline & & & & & & & & $\begin{array}{l}\text { for the } \\
\text { perimental } \\
\text { group }\end{array}$ & $\begin{array}{c}\text { for the con } \\
\text { group }\end{array}$ & trol \\
\hline
\end{tabular}


Vaccination benefits would potentially be greater in countries with low adherence to screening, but this strategy might be unaffordable in middle- and low-income countries given the current costs of the vaccine.

\section{CONCLUSION}

Currently available vaccines have proven effective and safe to prevent HPV serotypes 16 and 18 related CIN2+ lesions and to provide crossprotection against serotypes $31,33,45,52$ and 58, not included in the vaccine. Its long-term efficacy in preventing cervical cancer, however, has not yet been completely proven.

The cost-effectiveness of the vaccination program implementation in Latin America and the Caribbean is highly dependent on the cost of the vaccine in each country.

Funding: This meta-analysis was carried out as part of a study on health technology assessment thanks to the contribution of public agencies, non-governmental organizations, workers' unions health insurance organizations and private health insurance companies, for the development of reports of the area of Health Technology Assessment of Instituto de Efectividad Clínica y Sanitaria.

\section{Acknowledgments}

To all the members of the area of Health Technology Assessment of Instituto de Efectividad Clínica y Sanitaria, particularly Librarian Daniel Comandé.

\section{BIBLIOGRAPHY}

1. WHO. GLOBOCAN. Lyon, France: World Health Organization; 2008 [Accessed: 10.06.11]. Available at: http:// globocan.iarc.fr/.

2. zur Hausen H. Condylomata acuminata and human genital cancer. Cancer Res 1976;36(2 pt 2):794.

3. Koutsky L. Epidemiology of genital human papillomavirus infection. Am J Med 1997;102(5A):3-8.

4. Bosch FX, Manos MM, Munoz N, Sherman M, et al. Prevalence of human papillomavirus in cervical cancer: a worldwide perspective. International biological study on cervical cancer (IBSCC) Study Group. J Natl Cancer Inst 1995;87(11):796-802.

5. Ciapponi A, Bardach A, Glujovsky D, Gibbons L, Picconi MA. Type-specific HPV prevalence in cervical cancer and high-grade lesions in Latin America and the Caribbean: systematic review and meta-analysis. PLoS ONE 2011;6(10):e25493.

6. UNICEF. Immunization Summary, A statistical reference containing data through 2009. New York, USA: World Health Organization; 2011. [Accessed: July 7, 2012]. Available at: http:/ / www.childinfo.org/files/32775_UNICEF. pdf.
7. Sawaya GF, Smith-McCune K. HPV vaccination--more answers, more questions. N Engl J Med 2007;356(19):1991-3.

8. Miller NB, Raychaudhuri G, Toerner JG. Human papillomavirus vaccine. N Engl J Med 2007;357(11):1154-5; author reply 5-6.

9. ASCUS-LSIL, Traige, Study, (ALTS), Group. Results of a randomized trial on the management of cytology interpretations of atypical squamous cells of undetermined significance. Am J Obstet Gynecol 2003;188(6):1383-92.

10. Pagliusi SR, Teresa Aguado M. Efficacy and other milestones for human papillomavirus vaccine introduction. Vaccine 2004;23(5):569-78.

11. Wright TC, Jr., Cox JT, Massad LS, Carlson J, et al. 2001 consensus guidelines for the management of women with cervical intraepithelial neoplasia. Am J Obstet Gynecol 2003;189(1):295-304.

12. Paavonen J, Naud P, Salmeron J, Wheeler CM, et al. Efficacy of human papillomavirus (HPV)-16/18 AS04-adjuvanted vaccine against cervical infection and precancer caused by oncogenic HPV types (PATRICIA): final analysis of a double-blind, randomised study in young women. Lancet 2009;374(9686):301-14.

13. Wheeler CM, Kjaer SK, Sigurdsson K, Iversen OE, et al. The impact of quadrivalent human papillomavirus (HPV; types $6,11,16$, and 18) L1 virus-like particle vaccine on infection and disease due to oncogenic nonvaccine HPV types in sexually active women aged $16-26$ years. J Infect Dis 2009;199(7):936-44.

14. Harper DM, Franco EL, Wheeler CM, Moscicki AB, et al. Sustained efficacy up to 4.5 years of a bivalent L1 viruslike particle vaccine against human papillomavirus types 16 and 18: follow-up from a randomised control trial. Lancet 2006;367(9518):1247-55.

15. Muñoz N, Kjaer SK, Sigurdsson K, Iversen OE, et al. Impact of human papillomavirus (HPV)-6/11/16/18 vaccine on all HPV-associated genital diseases in young women. J Natl Cancer Inst 2010;102(5):325-39.

16. Garland SM, Hernández-Avila M, Wheeler CM, Pérez $\mathrm{G}$, et al. Quadrivalent vaccine against human papillomavirus to prevent anogenital diseases. N Engl J Med 2007;356(19):1928-43.

17. Future, II, Study, Group. Quadrivalent vaccine against human papillomavirus to prevent high-grade cervical lesions. N Engl J Med 2007;356(19):1915-27.

18. GoldieSJ, O Shea M, DíazM, KimSY. Benefits, cost requirements and cost-effectiveness of the HPV16,18 vaccine for cervical cancer prevention in developing countries: policy implications. Reproduct Health Matters 2008;16(32):86-96.

19. Goldie SJ, Kim JJ, Kobus K, Goldhaber-Fiebert JD, et al. Cost-effectiveness of HPV 16, 18 vaccination in Brazil. Vaccine 2007;25(33):6257-70.

20. Goldie SJ, Díaz M, Constenla D, Alvis N, et al. Mathematical Models of Cervical Cancer Prevention in Latin America and the Caribbean. Vaccine 2008;26(Suppl. 11):L59-L72.

21. Colantonio L, Gómez JA, Demarteau N, Standaert B, et al. Cost-effectiveness analysis of a cervical cancer vaccine in five Latin American countries. Vaccine 2009;27(40):5519-29.

22. Gutiérrez-Delgado C, Báez-Mendoza C, González-Pier E, de la Rosa AP, Witlen R. Relación costo-efectividad de las intervenciones preventivas contra el cáncer cervical en mujeres mexicanas: resultados de un modelo markoviano desde la perspectiva del sector público. Sal Publ Mex 2008;50(2):107-18.

23. Insinga RP, Dasbach EJ, Elbasha EH, Puig A, ReynalesShigematsu LM. Cost-effectiveness of quadrivalent human papillomavirus (HPV) vaccination in Mexico: A transmission dynamic model-based evaluation. Vaccine 2007;26(1):128-39. 
24. Reynales-Shigematsu LM, Rodrígues ER, Lazcano-PonceE. Cost-effectiveness analysis of a quadrivalent human papilloma virus vaccine in Mexico. Arch Med Res 2009;40(6):50313.

25. Kim JJ, Andres-Beck B, Goldie SJ. The value of including boys in an HPV vaccination programme: A cost-effectiveness analysis in a low-resource setting. Br J Cancer 2007;97(9):1322-8.
26. De La Hoz F, Alvis N, Narvez J, Gamboa O, Chocont A. Cost-effectiveness of human papillomavirus vaccine in Colombia in 2007. Value Health 2009;12 (3):A42.

27. Demarteau N, Suárez E, Gómez J, Standaert B. Modelling the impact of different vaccine profiles on the cost-effectiveness of HPV vaccination in the Chilean setting. Int J Gyn Obst 2009;107:S673-S4 